\title{
High hopanoid/total lipids ratio in Frankia mycelia is not related to the nitrogen status
}

\author{
Renaud Nalin, ${ }^{1}$ Surya Rosa Putra, ${ }^{2}$ Anne-Marie Domenach, ${ }^{1}$ \\ Michel Rohmer, ${ }^{2}$ François Gourbiere ${ }^{1}$ and Alison M. Berry ${ }^{3}$
}

Author for correspondence: Anne-Marie Domenach. Tel: +33 472431379. Fax: +3343721223. e-mail:domenach@biomserv.univ-lyon1.fr

1 Laboratoire d'Ecologie Microbienne, UMR CNRS 5557, Université Lyon 1, 43 Bld du 11 Novembre 1918, 69622 Villeurbanne Cedex France

2 Université Louis Pasteur/CNRS, Institut Le Bel, 4 rue Blaise Pascal, 67070 Strasbourg Cedex, France

3 Department of Environmental Horticulture, University of California, Davis, CA 95616, USA

\begin{abstract}
Vesicles are specific Frankia structures which are produced under nitrogenlimiting culture conditions. Hopanoids are the most abundant lipids in these vesicles and are believed to protect the nitrogenase against oxygen. The amounts and quality of each hopanoid were estimated in different Frankia strains cultivated under nitrogen-depleted and nitrogen-replete conditions in order to detect a possible variation. Studied Frankia strains nodulating Eleagnus were phylogenetically characterized by analysis of the nifD-K intergenic region as closely related to genomic species 4 and 5 .

Phylogenetically different strains belonging to three infectivity groups were cultivated in the same medium with and without nitrogen source for $10 \mathrm{~d}$ before hopanoid content analysis by HPLC. Four hopanoids together accounted for $23-87 \%$ and $15-87 \%$ of the total lipids under nitrogen-replete and nitrogen-depleted culture conditions, respectively. Two of the hopanoids found, bacteriohopanetetrols and their phenylacetic acid esters, have previously been described in Frankia. Two new hopanoids, moretan-29-ol and a bacteriohopanetetrol propionate, have also been identified. The moretan-29-ol and bacteriohopanetetrols were found to be the most abundant hopanoids whereas the bacteriohopanetetrol propionate and phenylacetates were present at a concentration close to the limit of detection. The ratio of (bacteriohopanetetrols + moretan-29-ol)/(total lipids) varied in most of the strains between nitrogen-depleted and nitrogen-replete culture conditions. In most of the strains, the hopanoid content was found to be slightly higher under nitrogen-replete conditions than under nitrogen-depleted conditions. These results suggest that remobilization, rather than neosynthesis of hopanoids, is implicated in vesicle formation in Frankia under nitrogendepleted conditions.
\end{abstract}

Keywords: Frankia strains, lipids, hopanoids, nitrogen

\section{INTRODUCTION}

Pentacyclic triterpenoids of the hopane series are widespread among bacteria (Rohmer et al., 1984). Zymomonas mobilis (Hermans et al., 1991), Alicyclobacillus acidocaldarius (Poralla et al., 1984) and Frankia (Berry et al., 1991) are known to contain a large percentage of hopanoids among their total lipids. According to their planar amphiphilic structure, hopanoids were proposed to act as sterol surrogates, i.e. as membrane stabilizers in prokaryotes (Rohmer et al., 1979). In Z. mobilis, they

The GenBank/EMBL/DDBJ accession numbers for the sequences in this paper are AJ251388-91 and AJ251393-4. were supposed to be implicated in the high degree of ethanol tolerance of this bacterium (Hermans et al., 1991; Schulenberg-Schell et al., 1989). In Al. acidocaldarius, an acidothermophilic bacterium, hopanoids were proposed to stabilize the membrane under high temperature and low $\mathrm{pH}$ conditions (Poralla et al., 1984). Under such extreme conditions, the adaptive response of the bacteria is to increase the amount of total hopanoid content.

Frankia is a nitrogen-fixing actinomycete which can form root nodules with woody plant hosts in eight angiosperm families. It is also able to fix nitrogen as a free-living organism over a wide range of oxygen concentrations (Silvester et al., 1990). Biological ni- 
trogen fixation constitutes a paradox for aerobic organisms as it relies on the oxygen-labile nitrogenase enzyme while, at the same time, the process is an energydemanding function which implies aerobic respiration. Aerobic nitrogen-fixing micro-organisms have developed strategies to regulate their intracellular oxygen concentration (for a review, see Gallon, 1992). Because Frankia can fix nitrogen under aerobic conditions, adaptive mechanisms for oxygen protection must exist.

In Frankia, the nitrogenase is localized in specialized structures called vesicles (Meesters et al., 1987). The vesicles differentiate mainly under nitrogen-limiting conditions. Each vesicle is surrounded by an external multilamellate lipid envelope which presumably functions as an oxygen diffusion barrier (Lamont et al., 1988; Harriott et al., 1991). Structural studies have shown that in cultured Frankia, the thickness of vesicle envelopes and the number of lipid layers increased in response to an increased oxygen concentration (Parsons et al., 1987). Four hopanoids, two bacteriohopanetetrol isomers, (Ia) and (Ib), and two bacteriohopanetetrol phenylacetyl monoesters, (IIa) and (IIb), represented $84 \%$ of the dry weight of purified vesicle envelope preparations (Berry et al., 1993), and $80 \%$ of the total lipids of vesicle clusters (Kleemann et al., 1994). Thus the bacteriohopanetetrols (Ia) and (Ib) together with their phenylacetic acid esters (IIa) and (IIb) were proposed to form the major physical barrier to protect nitrogenase against oxygen (Berry et al., 1993). It is not yet known whether these lipids might play an additional role in other stages of the Frankia life cycle. In Frankia strains HFPArI3 (Berry \& Torrey, 1979) and HFPCcI3 (Zhang \& Torrey, 1985), the two bacteriohopanetetrols represented a large fraction (20-50\%) of total lipids under nitrogen-replete conditions (Berry et al., 1991), but a comparison of hopanoids in different genomic species of Frankia, in cells grown under nitrogen-replete versus nitrogen-depleted conditions, has not yet been carried out.

In this report, we have quantified the ratio of hopanoids/total lipids, including the identification of new hopanoid structures in Frankia cells. This was realized in several Elaeagnus-compatible Frankia strains characterized by the nifD $-K$ region, and in two reference strains from the two other main infectivity groups, cultivated with and without nitrogen.

\section{METHODS}

Bacterial strains and growth conditions. Bacterial strains used in this study belong to the three main infectivity groups and are members of at least three different genomic species as defined by Fernandez et al. (1989). Frankia sp. HFPArI3 (Berry \& Torrey, 1979) and HFPCcI3 (Zhang \& Torrey, 1985) strains isolated from Alnus rubra Bong and Casuarina cunninghamiana, respectively, were used as reference strains. Elaeagnus-infective strains were isolated directly from nodules after plant trapping from a French soil (Nalin et al., 1997) on a BAP liquid medium without nitrogen (Murry et al., 1984). To ensure optimal vesicle production, each Frankia strain was cultivated three times. The first two subcultures were done in
$200 \mathrm{ml} \mathrm{BAP}$ medium either with or without nitrogen. In the latter case, the only nitrogen source, $\mathrm{NH}_{4} \mathrm{Cl}$, was suppressed. The second subculture was homogenized by syringedisrupting the Frankia cells through a $0.7 \times 30 \mathrm{~mm}$ sterile needle. From each culture type, $1 \mathrm{ml}$ homogenized Frankia cells was used to inoculate $10 \mathrm{ml}$ of the corresponding BAP medium, with propionate as carbon source for all strains except HFPCcI3, for which pyruvate was used. The last culture was maintained for $10 \mathrm{~d}$. Vesicles are formed in response to the limited availability of nitrogen after 1 week static culture (Fontaine et al., 1984; Murry et al., 1984). The presence of vesicles was verified by light microscopy.

Sequencing of PCR-amplified fragments. Elaeagnus-infective strains were characterized based on the PCR-RFLP HaeIII profile of the nifD-K region (Nalin et al., 1997). One representative strain of each nif-HaeIII profile was used for the $n i f D-K$ intergenic region identification. PCR amplifications were performed in a total volume of $50 \mu \mathrm{l}$, in $0.2 \mathrm{ml}$ Eppendorf tubes, using a thermocycler (9600; Perkin-Elmer).

Amplification of the nifD-K region directly from cells in liquid cultures was performed with primers FGPD807 (5'-CACTGCTACCGGTCGATGAA-3') and FGPK700' (5'-CGAGGTAGGTCTCGAAACCGG-3') as described by Jamann et al. (1993). Five microlitres of liquid culture was added to the reaction buffer $[10 \mathrm{mM}$ Tris $/ \mathrm{HCl}(\mathrm{pH} \mathrm{8.3),} \mathrm{1.5} \mathrm{mM} \mathrm{MgCl} 2$, $50 \mathrm{mM} \mathrm{KCl}, 0 \cdot 01 \%(\mathrm{w} / \mathrm{v}$ ) gelatin], $200 \mu \mathrm{M}$ each dNTP, $1 \mu \mathrm{M}$ each primer and 2.5 units Taq polymerase (Gibco-BRL). The following program was used: initial denaturation for $2 \mathrm{~min}$ at $94^{\circ} \mathrm{C}$, and 35 cycles of denaturation $\left(45 \mathrm{~s}\right.$ at $\left.95^{\circ} \mathrm{C}\right)$, annealing $\left(45 \mathrm{~s}\right.$ at $\left.55^{\circ} \mathrm{C}\right)$ and extension $\left(45 \mathrm{~s}\right.$ at $\left.72{ }^{\circ} \mathrm{C}\right)$, the final extension being longer $\left(2 \mathrm{~min}\right.$ at $\left.72{ }^{\circ} \mathrm{C}\right)$. Before sequencing, the amplification reaction mix was purified with Centricon-30 concentrators (Amicon-Grace). The amplicons were sequenced using the Amplicycle Sequencing Kit (Perkin-Elmer) by the direct sequencing method of Winship (1989). The two amplification primers were used as well as FGP-D169 [5'-ATGGACATCGC(CG)ATCAA-3'], FGP-K333' (5'-CCGGGCGAAGTGGCT- $\left.3^{\prime}\right)$ and FGP-K1 (5'-GTGACGACGACTCCC-3'), FGPK64' (5'-CCTCGTCCTTGAACA-3') described by Navarro et al. (1997). The sequences were determined on both strands (GenBank accession nos AJ251388-91 and AJ251393-4).

DNA sequence analysis. The phylogenetic analyses were based on the sequences of an approximately $420 \mathrm{bp}$ DNA fragment of the nifD-K intergenic region according to Nalin et al. (1999). Sequences were aligned and compared with the alignment of 14 closely related Frankia strains described by Navarro et al. (1997), using the multiple-alignment CLUSTAL X algorithm (Thompson et al., 1997), with manual refinements in the non-coding regions. Distances were calculated by pairwise comparison according to Kimura's two-parameter model (Kimura, 1980), and phylogenetic analyses were made using the neighbour-joining distance method of Saitou \& Nei (1987). The topology of the tree was tested by performing 1000 bootstraps (Felsenstein, 1985) and parsimony analysis (Swofford, 1993).

Lipid extraction and analysis. Total cultures were sonicated for $3 \mathrm{~min}$ at $60 \%$ of the maximal power and $50 \%$ active cycles (Sonifier 250; Branson UltraSonics) for each strain and each treatment and for three replicates. Lipids from the sonicated samples were extracted according to Bligh \& Dyer (1959) $\left(\mathrm{CHCl}_{3} / \mathrm{CH}_{3} \mathrm{OH} / \mathrm{H}_{2} \mathrm{O}, 2: 2: 1 \cdot 8\right.$, by vol., $\left.38 \mathrm{ml}\right)$. Total lipids extracted from each sample were concentrated under nitrogen to a volume of $50 \mu \mathrm{l}$ immediately prior to the HPLC injection.

Separation and detection of total lipids by HPLC was performed according to Moreau et al. (1990) on a silica gel Si- 
60 Lichrosorb column of $10 \mathrm{~cm}$ with an internal diameter of $5 \times 10^{-4} \mathrm{~cm}$ (Chrompack) at a flow rate of $0.5 \mathrm{ml} \mathrm{min}$. Quantifications were done with an evaporative light-scattering detector (ELSD IIA model; Varex) by integration of peak areas in the chromatogram (Kleemann et al., 1994).

HPLC peaks containing hopanoids were collected. Compounds were acetylated and identified by direct inlet impact MS according to the characteristic fragmentation ions of the triterpenoid pentacyclic skeleton, as described earlier (Berry et al., 1991). A large-scale culture of Frankia afforded enough material for the spectroscopic identification of the hopanoids. The structures of the novel hopanoids moretanol (IV) and bacteriohopanetetrol propionate (IV) and the stereochemistry of bacteriohopanetetrol (Ia) and (Ib) side chains were determined after isolation of the compounds by spectroscopic methods $\left({ }^{1} \mathrm{H}\right.$ - and $\left.{ }^{13} \mathrm{C}-\mathrm{NMR}, \mathrm{MS}\right)$, by derivatization and finally by comparison of the data with those obtained from synthetic reference compounds (Rosa Putra, 1998). The two bacteriohopanetetrols (Ia) and (Ib) only differed by the configuration at C-34 as shown by the comparison of the ${ }^{1} \mathrm{H}-\mathrm{NMR}$ spectra of their tetra-acetates with those of reference compounds (Bisseret \& Rohmer, 1989; Rosa Putra, 1998).

\section{RESULTS}

For each new isolate of Elaeagnus-infective Frankia strains, sequencing of the nifD-K intergenic spacer was carried out in order to compare them phylogenetically with the reference strains (Table 1). The length of the PCR products was of the expected size of approximately 1600 nucleotides. The length and the sequence composition of the nifD $-K$ region are highly conserved among the isolated Frankia strains. For all sequences, the nifD stop codon is TGA and the nifK initiation codon is GTG. A GGAGG sequence seven nucleotides upstream of the nifK initiation codon provides a ribosome-binding site (RBS) (Shine \& Dalgarno, 1974; results not shown).

Based on the sequences of a $420 \mathrm{bp}$ fragment from the nifD $-K$ intergenic region, phylogenetic relationships were investigated (Fig. 1). Elaeagnus-infective strains were subdivided into five groups corresponding to the four genomic species and an undescribed group. This separation was validated by parsimony analysis and bootstrap resamplings (with a threshold fitted at $99 \%$ of bootstraps). They are clustered together and distinct from Alnus- and Casuarina-infective strains. Most of the Elaeagnus-infective strains isolated were clustered with reference strain Ea1-12 corresponding to genomic species 4, which comprised EaI2, EaI3, EaI4 and EaI7. The EaI1 strain was clustered with $\mathrm{EaN}_{1}$-pec (genomic species 5), whereas strain EaI6 did not cluster with any of the other Elaeagnus-infective genomic species but was still in the coherent group of the Elaeagnus-infective strains.

The strains were grown under nitrogen-replete and -depleted conditions and the hopanoids were quantified by HPLC analysis. The two main groups (Fig. 2) in all strains were the $\mathrm{C}_{35}$ bacteriohopanetetrols (Ia) and (Ib) and the $\mathrm{C}_{30}$ moretan-29-ol (IV), whereas the bacteriohopanetetrol phenylacetates (IIa) and (IIb) and propionate (III) were close to the threshold of detection and could not be quantified. Under both culture conditions and for all strains from the three infectivity groups,

Table 1. Frankia strains isolated and used in this study

\begin{tabular}{|c|c|c|c|}
\hline Strain* & $\begin{array}{l}\text { GenBank } \\
\text { accession no. }\end{array}$ & Host plant & Reference \\
\hline EaI1 (U) S & AJ251388 & Elaeagnus angustifolia & Nalin et al. (1999) \\
\hline $\mathrm{EaI} 2(\mathrm{U}) \mathrm{S}$ & AJ251389 & Elaeagnus angustifolia & Nalin et al. (1999) \\
\hline $\mathrm{EaI} 3(\mathrm{U}) \mathrm{S}$ & AJ251390 & Elaeagnus angustifolia & Nalin et al. (1999) \\
\hline EaI4 (U) S & AJ251391 & Elaeagnus angustifolia & Nalin et al. (1999) \\
\hline EaI6 (U) S & AJ251393 & Elaeagnus angustifolia & Nalin et al. (1999) \\
\hline EaI7 (U) S & AJ251394 & Elaeagnus angustifolia & Nalin et al. (1999) \\
\hline Ea1-12 (4) & U63697 & Elaeagnus angustifolia & Navarro et al. (1997) \\
\hline $\mathrm{EaN}_{1}-$ pec $(5)$ & U63698 & Elaeagnus angustifolia & Navarro et al. (1997) \\
\hline EUN1f $(6)$ & L37664 & Elaeagnus umbellata & Navarro et al. (1997) \\
\hline HRN18a (7) & U63696 & Hypophaё rhamnohides & Navarro et al. (1997) \\
\hline SCN10a (U) & U63695 & Shepherdia canadensis & Navarro et al. (1997) \\
\hline $\mathrm{KP} 54(\mathrm{U})$ & U63694 & Gymnostoma poisonianum & Navarro et al. (1997) \\
\hline CN61 (U) & U63693 & Gymnostoma nodiflorum & Navarro et al. (1997) \\
\hline TC24 (U) & U63692 & Gymnostoma chamaecyparis & Navarro et al. (1997) \\
\hline MG59 (U) & U63691 & Gymnostoma glaucescens & Navarro et al. (1997) \\
\hline RPL61 (U) & U63334 & Gymnostoma leucodon & Navarro et al. (1997) \\
\hline D11 (atypical) (U) & U63700 & Casuarina equisetifolia & Navarro et al. (1997) \\
\hline $\mathrm{CcI} 3(9) \mathrm{S}$ & U63699 & Casuarina cunninghamiania & Hirsh et al. (1995) \\
\hline $\operatorname{ArI} 3$ (1) S & L35557 & Alnus rubra & Nalin et al. (1995) \\
\hline FaC1 & U53363 & Alnus viridis & Oh et al. (1997) \\
\hline
\end{tabular}

* Genomic species are in parentheses. U, Undetermined species; S, strains used in hopanoid analysis. 


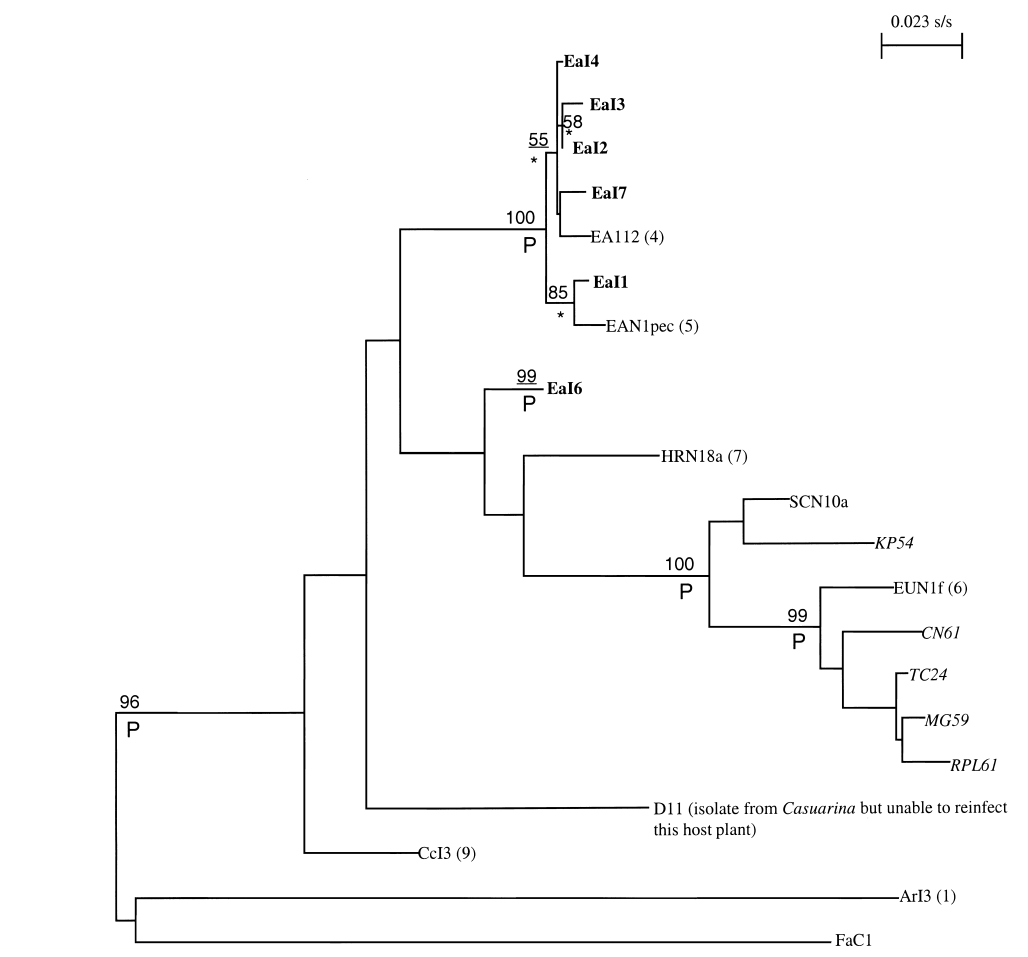

Fig. 1. Phylogenetic neighbour-joining tree based on nifD- $K$ intergenic spacer sequences. Bar, 0.023 substitutions per site. The isolates are in bold, the genomic species described by Fernandez et al. (1989) are in parentheses and the Gymnostoma-infective strains are in italic. $P$ indicates that the pairwise analysis is confirmed by parsimony analysis. The numbers are the percentages of bootstrap replicates in which the clusters were found.

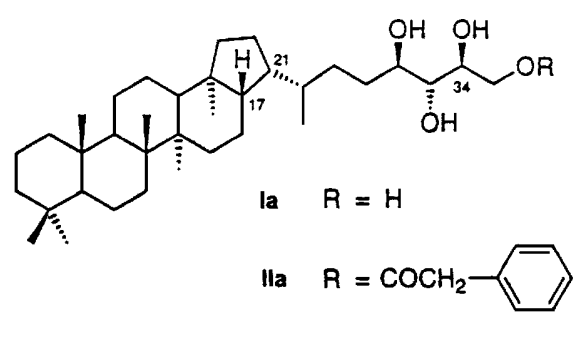

III $\mathrm{R}=\mathrm{COCH}_{2} \mathrm{CH}_{3}$

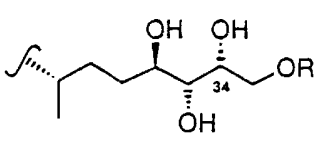

lb $R=H$

IIb

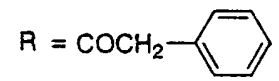

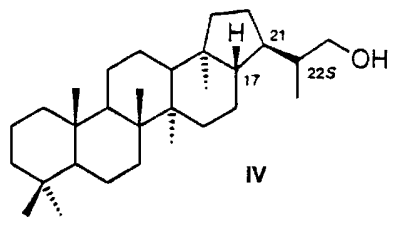

Fig. 2. Hopanoid structures of Frankia strains. la and Ib, bacteriohopanetetrols; Ila and IIb, bacteriohopanetetrophenylacetates; III, propionate; IV, moretan-29-ol.

hopanoids represented a large proportion of the total lipids (Table 2). A large variability was found in the hopanoid proportion among Frankia strains, ranging from 23 to $87 \%$ and from 15 to $88 \%$ of the total detected lipids, under nitrogen-replete and nitrogendepleted culture conditions, respectively. The variation in hopanoid content (hopanoids/total lipids ratio) between the two culture conditions represented between 10 and $20 \%$ of the total detected lipids. Under both culture conditions, the highest hopanoid content was found in the Elaeagnus-infective strains.
The two bacteriohopanetetrols (Ia) and (Ib) were the most abundant hopanoids in all the strains and for both culture conditions, and moretan-29-ol was the next most abundant triterpenoid (Table 2). However, the percentage of both hopanoids varied among strains and culture conditions in most cases, except in the EaI2 strain, where the bacteriohopanetetrol represented more than $80 \%$ of the lipids detected under both conditions. The highest percentage of moretan-29-ol was found in the EaI3 strain, representing $25 \%$ of the total lipids under nitrogen-replete conditions and decreasing to $3 \%$ 
Table 2. Proportion of the main hopanoids as a percentage of the total lipids in Frankia strains grown under nitrogen-replete $(+\mathrm{N})$ or nitrogen-depleted $(-\mathrm{N})$ culture conditions for $10 \mathrm{~d}$ (mean $\pm \mathrm{SE}, n=3-5)$

\begin{tabular}{|c|c|c|c|c|c|c|}
\hline \multirow[t]{2}{*}{ Strain } & \multicolumn{2}{|c|}{$\begin{array}{c}\text { Moretan-29-ol } \\
(\%)\end{array}$} & \multicolumn{2}{|c|}{$\begin{array}{c}\text { Bacteriohopanetetrols } \\
(\%)\end{array}$} & \multicolumn{2}{|c|}{$\begin{array}{c}\text { Total of the two } \\
\text { main hopanoids } \\
(\%)\end{array}$} \\
\hline & $+\mathrm{N}$ & $-\mathrm{N}$ & $+\mathrm{N}$ & $-\mathrm{N}$ & $+\mathrm{N}$ & $-\mathrm{N}$ \\
\hline EaI1 & $7 \pm 2 \cdot 0$ & $10 \pm 2 \cdot 0$ & $62 \pm 3 \cdot 0$ & $72 \pm 2$ & $69 \pm 3 \cdot 0$ & $82 \pm 3$ \\
\hline Eal2 & $5 \pm 1 \cdot 0$ & $2 \pm 0 \cdot 3$ & $82 \pm 2 \cdot 0$ & $85 \pm 1$ & $87 \pm 2 \cdot 0$ & $87 \pm 1$ \\
\hline Eal3 & $25 \pm 5 \cdot 0$ & $3 \pm 0 \cdot 3$ & $43 \pm 6 \cdot 0$ & $49 \pm 1$ & $68 \pm 10 \cdot 0$ & $52 \pm 1$ \\
\hline EaI4 & $4 \pm 1 \cdot 0$ & $4 \pm 1 \cdot 0$ & $83 \pm 1 \cdot 0$ & $65 \pm 2$ & $87 \pm 1 \cdot 0$ & $68 \pm 3$ \\
\hline EaI5 & $4 \pm 1 \cdot 0$ & $4 \pm 2 \cdot 0$ & $56 \pm 1 \cdot 0$ & $39 \pm 4$ & $60 \pm 2 \cdot 0$ & $43 \pm 6$ \\
\hline EaI6 & $14 \pm 0 \cdot 5$ & $8 \pm 2 \cdot 0$ & $65 \pm 0 \cdot 3$ & $53 \pm 1$ & $79 \pm 0 \cdot 1$ & $61 \pm 0 \cdot 3$ \\
\hline ArI3 & $5 \pm 1 \cdot 0$ & $3 \pm 0 \cdot 3$ & $17 \pm 1 \cdot 0$ & $40 \pm 1$ & $23 \pm 3 \cdot 0$ & $42 \pm 1$ \\
\hline CcI3 & $12 \pm 1 \cdot 0$ & $2 \pm 0 \cdot 1$ & $21 \pm 0 \cdot 2$ & $13 \pm 1$ & $33 \pm 1 \cdot 0$ & $15 \pm 1$ \\
\hline
\end{tabular}

under nitrogen-depleted conditions. In contrast, this compound represented only $4 \%$ of the total detected lipids in the EaI4 and EaI5 strains under both conditions (Table 2).

\section{DISCUSSION}

Adaptation of bacteria to fluctuating environmental conditions represents one of the emerging domains of microbiology. In particular, nitrogen-fixing bacteria must deal with a critical situation with respect to membrane permeability, and hopanoids that would be involved in protecting nitrogenase from oxygen diffusion (Berry et al., 1993) have been postulated to play an important role in that adaptation in their saprophytic and symbiotic lives.

The nifD-K region, which has been widely used for the characterization of new Frankia isolates (Navarro et al., 1997), permits the discrimination between two closely related Alnus-infective strains (Nalin et al., 1995). The nifD $-K$ intergenic spacer sequences have been used to characterize newly detected Gymnostoma-infective Frankia strains, which were found to be clustered with the Elaeagnus-infectivity group confirming the plant nodulation bioassay (Navarro et al., 1997). This region allows for discrimination at the infraspecific level and thus is very useful for strain characterization in the Frankia genus.

In Elaeagnus-infective strains, we confirm and extend earlier observations on Frankia hopanoids (Berry et al., 1991, 1993): bacteriohopanetetrols (Ia) and (Ib) and their phenylacetates (IIa) and (IIb) belong to the main triterpenoids found in these bacteria. In addition, two novel hopanoids were identified: a bacteriohopanetetrol propionate (III) as a minor compound and, surprisingly, moretan-29-ol (IV), which was one of the major hopanoids (Rosa Putra, 1998). Detailed structure determinations will be reported elsewhere. This is the first report of a $(17 \beta-\mathrm{H}, 21 \alpha-\mathrm{H})$ hopanoid from a prokaryote. The presence of such a $C_{30}$ triterpene is a striking feature, and its significance is not clear. Over 30 hopanoid structures have been described from bacteria (Ourisson \& Rohmer, 1992; Rohmer, 1993). They primarily differ by their side chain structures. Hopanoids have already been found in nitrogen-fixing bacteria, such as Azotobacter vinelandii, Beijerinckia indica and Beijerinckia mobilis (Vilchèze et al., 1994), and in the Bradyrhizobium species (Kannenberg et al., 1996), but not in all of them. No common structural features were found, however, for the hopanoid side chains in nitrogen-fixing bacteria. The significance of such structural diversity is not obvious. Hopanoids were assumed to act as membrane stabilizers, in a fashion similar to that of sterols in eukaryotic membranes (Ourisson \& Rohmer, 1992). Such a structural role is compatible with molecular diversity, provided the triterpenoids fulfil all structural features required for membrane stabilizers (Rohmer et al., 1979; Simonin et al., 1992). Our findings of additional hopanoids in Frankia strains, especially the moretan-29-ol, under nitrogen-replete conditions are highly suggestive that hopanoids might be implicated in other processes besides the oxygen protection of nitrogenase.

The total amount of hopanoids has been estimated at approximately $35 \mathrm{mg}$ (g lyophilized cells) ${ }^{-1}$ (data not shown). All Frankia strains tested from three infectivity groups show a high hopanoids/lipids ratio, expanding the results obtained by Berry et al. (1991) on strains HFPArI3 and HFPCcI3. This ratio was found to be much higher than those of other hopanoid-producing bacteria, even higher than those of Z. mobilis (Hermans et al., 1991) and Al. acidocaldarius (Poralla et al., 1984), which were previously known to produce the highest amounts of hopanoids. This suggests that the large amount of hopanoids $(20-87 \%$ of total lipids) is a general feature of the Frankia genus and could be used as a phenotypic characteristic of this genus among actino- 
mycetes (Marechal et al., 2000). Such high concentrations are probably not compatible with their commonly accepted role as membrane stabilizers, at least in the way described for sterols interacting with the phospholipid side chains.

The moretan-29-ol (IV) and the bacteriohopanetetrols (Ia) and (Ib), the most abundant hopanoids in Frankia cells, have been found in different ratios among the Frankia strains tested. Quantitative variations under the alternative nitrogen conditions were much less important in our experiments, since such variation represented only up to $20 \%$. A similar result was found in another nitrogen-fixing bacterium, Az. vinelandii, where production of hopanoids was not stimulated under nitrogen-fixing conditions (Vilchèze et al., 1994).

The consistently high proportion of hopanoids observed, even under nitrogen-replete conditions, indicates that in all tested Frankia strains, most of the hopanoids are synthesized independently of the nitrogen source of the culture. Nevertheless, hopanoids are the main lipid component of the vesicles (Kleemann et al., 1994), which are essentially produced under nitrogenfixing conditions. This suggests that hopanoids could be remobilized rather than neosynthesized under nitrogenfree culture conditions in order to build up the multilamellate envelope of the vesicles.

The structural diversity of hopanoids and their high proportion in all Frankia populations over different infectivity groups suggest that these compounds play important roles in Frankia cells. Their roles could be expressed in symbiotic interactions, i.e. in root nodules, where hopanoids were first reported (Berry et al., 1991), and also under in vitro culture conditions, where they represent up to $87 \%$ of the total lipids detected. Hopanoids might have a fundamental function in Frankia ecology, and the variations observed in the hopanoid concentration between strains would be the expression of different adaptive capacities. This hypothesis might point to new functions for hopanoids that are currently being tested.

\section{ACKNOWLEDGEMENTS}

We thank Dr M. L. Bouillant, Dr P. Normand (University Lyon I) and Dr D. Jones for helpful comments and C. Pettit (UC Davis) for technical assistance. S. R.P. was on leave from the Institute of technology " $10^{\text {th }}$ November" (Surabaya, Indonesia) and was supported by a grant from the Indonesian High Education Project and Asian Development Bank (no. 1253-INO, 1994). This investigation was supported by grants to M.R. from the 'Institut Universitaire de France' and from the European Union Biomass project (contract no. ENV4-CT 95-0026).

\section{REFERENCES}

Berry, A. M. \& Torrey, J. G. (1979). Isolation and characterisation in vivo and in vitro of an actinomyceteous endophyte from Alnus rubra Bong. In Symbiotic Nitrogen Fixation in the Management of Temperate Forests, pp. 69-83. Edited by J. C. Gordon, C. T.
Wheeler \& D. A. Perry. Corvallis: Oregon State University, Forest Research Laboratory.

Berry, A. M., Moreau, R. A. \& Jones, A. D. (1991). Bacteriohopanetetrol: abundant lipid in Frankia cells and in nitrogenfixing nodule tissue. Plant Physiol 95, 111-115.

Berry, A. M., Harriott, O. T., Moreau, R. A., Osman, S. F., Benson, D. R. \& Jones, A. D. (1993). Hopanoid lipids compose the Frankia vesicle envelope, presumptive barrier of oxygen diffusion to nitrogenase. Proc Natl Acad Sci US A 90, 6091-6094.

Bisseret, P. \& Rohmer, M. (1989). Bacterial sterol surrogates. Determination of the absolute configuration of bacteriohopanetetrol side chain by hemisynthesis of its diastereoisomers. J Org Chem 54, 2958-2964.

Bligh, E. G. \& Dyer, W. J. (1959). A rapid method of total lipid extraction and purification. Can J Biochem Physiol 37, 911-917.

Felsenstein, J. (1985). Confidence limits on phylogenies : approach using bootstrap. Evolution 39, 783-791.

Fernandez, M. P., Meugnier, H., Grimont, P. A. D. \& Bardin, R. (1989). Deoxyribonucleic acid relatedness among members of the genus Frankia. Int J Syst Bacteriol 39, 424-429.

Fontaine, M. S., Lancelle, S. A. \& Torrey, J. G. (1984). Initiation and ontogeny of vesicles in cultured Frankia sp. strain HFPArI3. J Bacteriol 160, 921-927.

Gallon, J. R. (1992). Reconciling the incompatible: $\mathrm{N}_{2}$ fixation and $\mathrm{O}_{2}$. New Phytol 122, 571-609.

Harriott, O. T., Khairallah, L. \& Benson, D. R. (1991). Isolation and structure of the lipid envelopes from the nitrogen-fixing vesicles of Frankia sp. strain CpI1. J Bacteriol 173, 2061-2067.

Hermans, M. A. F., Neuss, B. \& Sahm, H. (1991). Content and composition of hopanoids in Zymomonas mobilis under various growth conditions. J Bacteriol 173, 5592-5595.

Hirsh, A., McKhann, H., Reddy, A., Liao, J., Fang, Y. \& Marshall, C. (1995). Assessing horizontal transfer of nif HDK genes in eubacteria: nucleotide sequence of nif $\mathrm{K}$ from Frankia strain HFPCcI3. Mol Biol Evol 12, 16-27.

Jamann, S., Fernandez, M. P. \& Normand, P. (1993). Typing method for $\mathrm{N}_{2}$-fixing bacteria based on PCR/RFLP application to the characterization of Frankia strains. Mol Ecol 2, 17-26.

Kannenberg, E. L., Perzi, M., Muller, P., Hartner, T. \& Poralla, K. (1996). Hopanoid lipids in Bradyrhizobium and other plantassociated bacteria and cloning of the Bradyrhizobium squalenehopene cyclase. Plant Soil 186, 107-112.

Kimura, M. (1980). A simple method for estimating evolutionary rates of base substitutions through comparative studies of nucleotide sequences. J Mol Evol 16, 111-120.

Kleemann, G., Alskog, G., Berry, A. M. \& Huss-Danell, K. (1994). Lipid composition and nitrogenase activity of the symbiotic Frankia (Alnus incana) in response to different oxygen concentrations. Protoplasma 183, 107-115.

Lamont, L. H., Silvester, B. \& Torrey, J. G. (1988). Nile red fluorescence demonstrates lipid in the envelope of vesicles from $\mathrm{N}_{2}$-fixing cultures of Frankia. Can J Microbiol 34, 656-660.

Marechal, J., Clement, B., Nalin, R., Gandon, C., Orso, S., Cvejic, H., Bruneteau, M., Berry, A. M. \& Normand, P. (2000). A recA gene analysis confirms the close proximity of Frankia to Acidothermus. Int J Syst Evol Microbiol 50, 781-785.

Meesters, T., van Vliet, M. \& Akkermans, A. (1987). Nitrogenase is restricted to the vesicles in Frankia strain EAN1pec. Physiol Plant 70, 267-271.

Moreau, R. A., Asmann, P. T. \& Norman, H. A. (1990). Quantitative analysis of the major classes of plant lipids by high 
performance liquid chromatography and flame ionization detection (HPLC-FID). Phytochemistry 29, 2461-2466.

Murry, M., Fontaine, M. S. \& Torrey, J. G. (1984). Growth kinetics and nitrogenase induction in Frankia sp. HFP ArI3 grown in batch culture. Plant Soil 78, 61-78.

Nalin, R., Domenach, A. M. \& Normand, P. (1995). Molecular structure of the Frankia spp. nifD-K intergenic spacer and design of Frankia genus compatible primer. Mol Ecol 4, 483-491.

Nalin, R., Normand, P. \& Domenach, A. M. (1997). Distribution and $\mathrm{N}_{2}$-fixing activity of Frankia strains in relation with soil depth. Physiol Plant 99, 732-738.

Nalin, R., Normand, P., Simonet, P. \& Domenach, A. M. (1999). Polymerase chain reaction and hybridization on DNA extracted from soil as a tool for Frankia spp. population distribution studies in soil. Can J Bot 77, 1239-1247.

Navarro, E., Nalin, R., Gauthier, D. \& Normand, P. (1997). The nodular microsymbionts of Gymnostoma spp. are Elaeagnusinfective Frankia strains. Appl Environ Microbiol 63, 1610-1616.

Oh, B., Twiggs, P., Hong, J., Mullin, B. \& An, C. (1997). nif V is contiguous to nif HDK in Frankia strain FaC1. Physiol Plant 99, 707-713.

Ourisson, G. \& Rohmer, M. (1992). The hopanoids. Part 2: the biohopanoids, a novel class of bacterial lipids. Accounts Chem Res 25, 403-407.

Parsons, R., Silvester, W., Harris, S., Gruijters, W. \& Bullivant, S. (1987). Frankia vesicles provide inducible and absolute oxygen protection for nitrogenase. Plant Physiol 83, 728-731.

Poralla, K., Härtner, T. \& Kannenberg, E. (1984). Effect of temperature and $\mathrm{pH}$ on the hopanoid content of Bacillus acidocaldarius. FEMS Microbiol Lett 23, 253-256.

Rohmer, M. (1993). The biosynthesis of triterpenoids by the hopane series in Eubacteria: a mine of new enzyme reactions. Pure Appl Chem 65, 1293-1298.

Rohmer, M., Bouvier, P. \& Ourisson, G. (1979). Molecular evolution of biomembranes: structural equivalents and phylogenetic precursors of sterols. Proc Natl Acad Sci USA $\mathbf{7 6}$, 847-851.

Rohmer, M., Bouvier-Nave, P. \& Ourisson, G. (1984). Distribution of hopanoid triterpenes in prokaryotes. J Gen Microbiol 130, 1137-1150.
Rosa Putra, S. (1998). Rôle du 1-désoxy-D-xylulose dans la biosynthèse des isoprénoides. $\mathrm{PhD}$ thesis, Université Louis Pasteur, Strasbourg, France.

Saitou, R. R. \& Nei, M. (1987). A neighbour-joining method: a new method for reconstructing phylogenetic trees. Mol Biol Evol 4, 406-425.

Schulenberg-Schell, H., Neuss, B. \& Sahm, H. (1989). Quantitative determination of various hopanoids in microorganisms. Anal Biochem 181, 120-124.

Shine, J. \& Dalgarno, L. (1974). The 3'-terminal sequence of Escherichia coli $16 \mathrm{~S}$ ribosomal RNA : complementary to nonsense triplets and ribosome binding sites. Proc Natl Acad Sci U S A 71, 1342-1346.

Silvester, W. B., Harris, S. L. \& Tjepkema, J. D. (1990). Oxygen regulation and hemoglobin. In The Biology of Frankia and Actinorhizal Plants, pp. 157-173. Edited by C. R. Schwintzer \& J. D. Tjepkema. New York: Academic Press.

Simonin, P., Jürgens, U. J. \& Rohmer, M. (1992). 35-0- $\beta-6-A m i n o-$ 6-deoxyglucopyranosyl bacteriohopanetetrol, a novel triterpenoid of the hopane series from the cyanobacterium Synechocystis sp. PCC 6714. Tetrahedron Lett 33, 3629-3632.

Swofford, D. L. (1993). PAUP - phylogenetic analysis using parsimony, version 3.1. Illinois Natural History Survey, Champaign.

Thompson, J. D., Gibson, T. J., Plewniak, F., Jeanmougin, F. \& Higgins, D. G. (1997). The CLUSTAL-X windows interface: flexible strategies for multiple sequence alignment aided by quality analysis tools. Nucleic Acids Res 25, 4876-4882.

Vilchèze, C., Llopiz, P., Neunlist, S., Poralla, K. \& Rohmer, M. (1994). Prokaryotic triterpenoids: new hopanoids from the nitrogen-fixing bacteria Azotobacter vinelandii, Beijerinckia indica and Beijerinckia mobilis. Microbiology 140, 2749-2753.

Winship, P. R. (1989). An improved method for directly sequencing PCR amplified material using dimethyl sulfoxide. Nucleic Acids Res 17, 1266.

Zhang, Z. \& Torrey, J. G. (1985). Studies of an effective strain of Frankia from Allocasuarina lehmanniana of the Casuarinaceae. Plant Soil 87, 1-16.

Received 14 April 2000; revised 4 July 2000; accepted 18 July 2000 